\title{
Analysis of DNA Content, Nitrogenase Activity and In Vivo Protein Synthesis of Rhizobium leguminosarum Bacteroids on Sucrose Gradients
}

\author{
By R. C. VAN DEN BOS, T. BISSELING AND A. VAN KAMMEN \\ Department of Molecular Biology, Agricultural University, \\ Wageningen, The Netherlands
}

(Received 17 May 1978)

\begin{abstract}
Bacteroids of Rhizobium leguminosarum (strain PRE) isolated from pea root nodules (Pisum sativum) were separated by sucrose density gradient centrifugation, according to their stage of development from bacteria to mature bacteroids. The DNA content per cell, as measured by cytofluorometry, increased with development. Nitrogenase components in soluble bacteroid proteins were present in highest concentrations in mature bacteroids. The ratio of the amounts of Mo-Fe protein to $\mathrm{Fe}$ protein was not constant in different stages of development. Incorporation of ${ }^{35} \mathrm{SO}_{4}{ }^{2-}$ into soluble bacteroid proteins in the nodule was maximal in the youngest stages. In mature bacteroids nitrogenase was synthesized preferentially although less ${ }^{35} \mathrm{SO}_{4}{ }^{2-}$ was incorporated into total soluble protein. Nitrogenase activity, measured as ATP- and $\mathrm{S}_{2} \mathrm{O}_{4}{ }^{2-}$-dependent acetylene reduction by EDTA/toluene treated bacteroids, was high in mature bacteroids and low in the youngest stages.
\end{abstract}

\section{INTRODUCTION}

Studies on the structural organization of pea root nodules after infection with Rhizobium leguminosarum have shown that plant cells containing bacteroids of different ages coexist within a single nodule. Cells at the base of the nodule contain older and degenerating bacteroids, whereas in the apical region of the nodule, younger actively-dividing rhizobia are found, sometimes lacking the characteristic bacteroid appearance (Van Brussel, 1973; Kijne, 1975). It is not known, however, in which stage of development the bacteroids are most active in synthesizing nitrogenase or when nitrogen fixation occurs. Recently, Sutton \& Mahoney (1977) described the fractionation of bacteroids of $R$. lupini of different sizes by sucrose gradient centrifugation. Since there is a direct correlation between the size and the age of bacteroids (Bisseling et al., 1977; Van Brussel, 1973), we have used this technique to separate bacteroids of different developmental stages. The DNA content, nitrogen-fixing activity and protein-synthesizing capacity of bacteroids banding in different regions of sucrose gradients were compared in an attempt to follow their development.

\section{METHODS}

Culture and labelling conditions. Rhizobium leguminosarum (strain PRE) was cultured as described by Reijnders et al. (1975) and harvested at the end of the exponential growth phase. Pisum sativum (var. 'Rondo') was grown in gravel (sterilized by heating for $2 \mathrm{~h}$ at $120^{\circ} \mathrm{C}$ ) and inoculated with $R$. leguminosarum (strain PRE) at time zero. The plants were grown in the medium described by Reijnders et al. (1975). After $17 \mathrm{~d}$ the plants were transferred to plastic trays $(30 \times 15 \mathrm{~cm}, \times 15 \mathrm{~cm}$ deep). The plants were supported by cotton wool plugs in holes $(1 \mathrm{~cm}$ diam.) in the lid of the tray; 15 to 20 plants were kept in one tray and the level of the nutrient medium was kept below the nodules. Other growth conditions were as described by Bisseling et al. (1978). At day 18 the medium was replaced by a sulphur-deficient medium. Plants were labelled from 
day 20 to day 21 (for $24 \mathrm{~h}$ ) with ${ }^{35} \mathrm{SO}_{4}{ }^{2-}$ (carrier-free, The Radiochemical Centre, Amersham) using $150 \mu \mathrm{Ci}$ per plant. After labelling the roots were rinsed with distilled water to remove excess label and the nodules were picked immediately using forceps.

Isolation of bacteroids and gradient centrifugation. Nodules from 10 plants (about $0.5 \mathrm{~g}$ ) were ground in a mortar with $2 \mathrm{ml} 0.5 \mathrm{M}$-mannitol, $50 \mathrm{~mm}$-Tris/ $\mathrm{HCl}$ buffer $\mathrm{pH} 7 \cdot 4$. The suspension was filtered through Miracloth (Calbiochem) and layered on a $25 \mathrm{ml}$ linear sucrose gradient $[12$ to $30 \%(\mathrm{w} / \mathrm{v})$ sucrose in 50 $\mathrm{mM}$-Tris $/ \mathrm{HCl}$ buffer $\mathrm{pH} 7 \cdot 4]$ contained in glass tubes $(2 \times 9 \mathrm{~cm})$. The gradients were centrifuged for $15 \mathrm{~min}$ at $1500 \mathrm{~g}$, and decelerated without braking. Using a peristaltic pump, the gradients were fractionated from the bottom through a glass capillary. Care was taken to place the capillary beside the pellet at the bottom of the tube. Fractions $(0.85$ or $1.70 \mathrm{ml})$ were centrifuged for $5 \mathrm{~min}$ at $12000 \mathrm{~g}$ and the pellets were washed in $1 \mathrm{ml}$ mannitol/Tris buffer. Samples of each bacteroid fraction were smeared on microscope slides for determination of the DNA content per cell (Bisseling et al., 1977).

Lysis of the cells. Bacteroids were lysed by resuspension of the pellet in $250 \mu \mathrm{l} 25 \mathrm{~mm}-\mathrm{Tris} / \mathrm{HCl}$ buffer $\mathrm{pH}$ $7 \cdot 5$, containing $1 \%(\mathrm{v} / \mathrm{v})$ Triton X-100 and $1 \mathrm{~mm}$-dithioerythritol (Sigma), and incubation for $2 \mathrm{~h}$ at $4{ }^{\circ} \mathrm{C}$. For the preparation of samples for gel electrophoresis the buffer also contained $20 \mathrm{~mm}-\mathrm{Na}_{2} \mathrm{~S}_{2} \mathrm{O}_{4}$ and all manipulations until the addition of sample buffer were done under a stream of argon. The supernatant obtained by centrifuging at $12000 \mathrm{~g}$ for $5 \mathrm{~min}$ was taken as the lysate. To a sample of the lysate, an equal volume of $10 \%(\mathrm{w} / \mathrm{v})$ perchloric acid was added and, after centrifuging, the protein in the pellet was determined according to Lowry et al. (1951), using bovine serum albumin as a standard.

Measurement of radioactivity incorporated into proteins. Radioactive proteins were precipitated in the presence of $100 \mu \mathrm{g}$ bovine serum albumin as carrier: $100 \mu \mathrm{l}$ albumin $\left(1 \mathrm{mg} \mathrm{ml}^{-1}\right)$ was added to 0.05 to 0.1 $\mathrm{ml}$ lysate and proteins were precipitated by adding an equal volume of $10 \%$ perchloric acid. The precipitated protein was collected on Whatman GF/C filters and washed with $5 \%$ perchloric acid and then acetone. The filters were dried at $60^{\circ} \mathrm{C}$ in scintillation vials. After incubation with $0.5 \mathrm{ml}$ Soluene 350 (Packard, Zürich, Switzerland) at $40{ }^{\circ} \mathrm{C}$ overnight, $10 \mathrm{ml}$ Instafluor (Packard) was added and ${ }^{35} \mathrm{~S}$ radioactivity was determined using a liquid scintillation spectrometer.

Sodium dodecyl sulphate gel electrophoresis. Proteins were separated by electrophoresis in $11 \%(\mathrm{w} / \mathrm{v})$ polyacrylamide slab gels containing sodium dodecyl sulphate (SDS; Serva Fine Biochemicals, Heidelberg, Germany) as described by Bisseling et al. (1978); 20 to $100 \mu$ lysate was loaded in each sample well. The gels were stained with Coomassie Brilliant blue. To determine the amounts of ${ }^{35} \mathrm{~S}$ in various proteins, the bands were cut from the gel and incubated in $0.1 \mathrm{ml}$ water plus $0.9 \mathrm{ml}$ Soluene 350 for $16 \mathrm{~h}$ at $40^{\circ} \mathrm{C}$. After adding $10 \mathrm{ml}$ Instafluor, ${ }^{35} \mathrm{~S}$ radioactivity was measured in a liquid scintillation spectrometer.

Measurement of DNA content per bacteroid cell. This was determined as described by Bisseling et al. (1977).

Nitrogenase activity of separated bacteroids. Nodules from 30 to 50 plants were disrupted anaerobically in $50 \mathrm{~mm}$-Tris/HCl buffer pH 7.2, containing $20 \mathrm{mM}-\mathrm{Na}_{2} \mathrm{~S}_{2} \mathrm{O}_{4}, 2.5 \mathrm{mM}-\mathrm{MgCl}_{2}$ and $4 \%$ (w/v) polyvinylpyrrolidone, as described by Van Straten \& Roelofsen (1976). A $2 \mathrm{ml}$ sample of the suspension was layered over a 12 to $30 \%$ sucrose gradient containing $20 \mathrm{~mm}-\mathrm{Na}_{2} \mathrm{~S}_{2} \mathrm{O}_{4}$ and covered with a thin layer of paraffin oil to avoid contact with air. The gradient was centrifuged $(15 \mathrm{~min}$ at $1500 \mathrm{~g})$ and fractionated into bottles $(6 \mathrm{ml})$ filled with $\mathrm{N}_{2}$ and capped with Suba-seals. To each fraction, an equal volume of $50 \mathrm{~mm}-\mathrm{Tris} / \mathrm{HCl}$ buffer $\mathrm{pH} 7 \cdot 2$, containing $2.5 \mathrm{~mm}-\mathrm{MgCl}_{2}, 20 \mathrm{~mm}-\mathrm{Na}_{2} \mathrm{~S}_{2} \mathrm{O}_{4}$ and $1 \mathrm{~mm}$-EDTA, and 3 drops of toluene were added. The mixture was shaken vigorously for $1 \mathrm{~min}$ in a rotary shaker and left to stand for $5 \mathrm{~min}$. Samples $(1 \mathrm{ml})$ were withdrawn with a syringe, taking care not to disturb the toluene layer on top of the mixture. Each sample was added to $1 \mathrm{ml} 50 \mathrm{mM}$-Tris/ $\mathrm{HCl}$ buffer $\mathrm{pH} 7 \cdot 4$, containing $18.4 \mathrm{~mm}$-creatine phosphate, 26.2 mM- $\mathrm{MgCl}_{2}, 5.6 \mathrm{~mm}-\mathrm{ATP}$ and $20 \mathrm{mM}-\mathrm{Na}_{2} \mathrm{~S}_{2} \mathrm{O}_{4}$, and $15 \mu \mathrm{g}$ creatine kinase in a $6 \mathrm{ml}$ bottle sealed with a Suba-seal. The gas phase contained $10 \%(\mathrm{v} / \mathrm{v})$ acetylene in nitrogen. After 20 min incubation in a shaking bath at $30^{\circ} \mathrm{C}$, a $100 \mu \mathrm{l}$ gas sample was removed with a syringe and analysed in a gas chromatograph for the amount of ethylene formed to determine the acetylene reduction. Acetylene reduction activity is expressed in nmol ethylene produced in $20 \mathrm{~min}$.

Materials. All materials used were reagent grade.

\section{RESULTS}

\section{Localization of different types of bacteroids within the nodule}

Nodules from $21 \mathrm{~d}$-old pea plants were cut parallel to the root into two parts of approximately equal size and the apical and basal parts were collected separately. To each of the cut nodule portions, approximately $20 \%(\mathrm{w} / \mathrm{w})$ of intact ${ }^{35} \mathrm{~S}$-labelled nodules of the same age was added, as an internal marker for the sedimentation rate. The nodules were ground in a mortar and bacteroids from the apical and basal parts were isolated and centrifuged on 


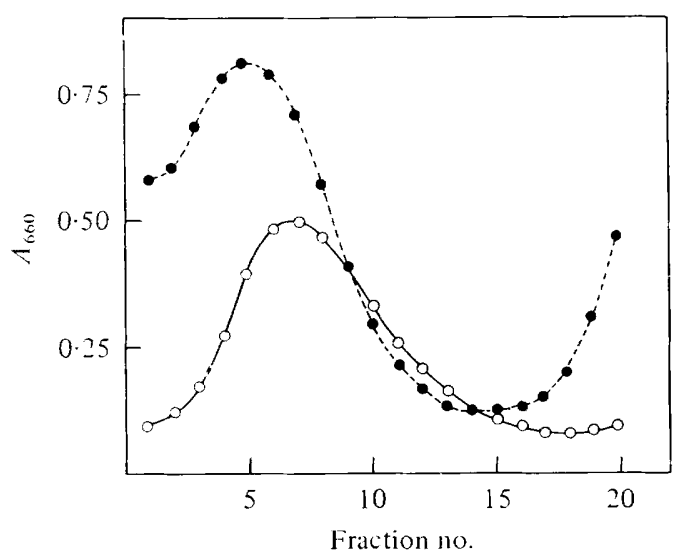

Fig. 1. Sucrose gradient fractionation of bacteroids isolated from the apical and basal parts of 21 d-old pea root nodules. Nodule fractions were mixed with ${ }^{35} \mathrm{~S}$-labelled nodules as described in the text and fractionated on two similar sucrose gradients. The sedimentation patterns of "basal" $(\odot)$ and 'apical' $(O)$ bacteroids are shown. The sedimentation pattern of the ${ }^{35} \mathrm{~S}$-labelled bacteroids added as a sedimentation marker and to align the sedimentation patterns is not shown. Sedimentation was from right to left.

sucrose gradients (12 to $30 \%$ ) in the same run. After centrifuging, a small white pellet (probably consisting of starch), which did not contain bacteria or bacteroids, was always visible in the tube. The bacteroids were present as a broad opalescent band in the middle of the gradient, and a reddish band of soluble plant proteins including leghaemoglobin was found at the top of the gradient. The gradients were fractionated and the absorbance $\left(A_{660}\right)$ and radioactivity of fractions were determined. The younger bacteroids from the apical part of the nodule sedimented slower than the older bacteroids found in the basal region (Fig. 1).

\section{Sucrose gradient centrifugation of bacteroids and determination of DNA per cell}

The DNA content of bacteroids increases with size (Bisseling et al., 1977) and, for $R$. lupini bacteroids, those which sediment fastest in a sucrose gradient contain the most DNA (Sutton et al., 1978). Rhizobium leguminosarum bacteroids have branched structures and are morphologically different from $R$. lupini bacteroids which are long rods. Therefore we repeated the fractionation of $R$. leguminosarum bacteroids on sucrose gradients and determined the DNA content per cell (Fig. $2 a$ ). We used bacteroids from nodules of 10 pea plants $21 \mathrm{~d}$ after inoculation; such plants have well-developed nodules and show a high nitrogen-fixing activity (Bisseling et al., 1978). As with $R$. lupini, the largest bacteroids contained two to three times more DNA per cell than the rod-like structures. A separation of the different classes of bacteroids [rods (which includes cells of the same size as broth cultured free-living bacteria), ramified forms and extra-ramified forms] was evident (Fig. $2 b$ ). Short rods resembling broth-cultured bacteria were only seen in the slower sedimenting fractions of the bacteroid peak. Only fractions 13 to 15 contained material of plant origin, in accordance with the work of Sutton \& Mahoney (1977).

We conclude that gradient centrifugation separates bacteroids of $R$. leguminosarum of different developmental stages.

\section{Protein synthesizing activity of different bacteroid forms}

Whole plants were labelled for $24 \mathrm{~h}$ with carrier-free ${ }^{35} \mathrm{SO}_{4}{ }^{2-}$ (see Methods); during this time 80 to $95 \%$ of the total radioactivity was taken up by the plants. When the isolated bacteroids were separated by sucrose gradient centrifugation, the fractions whose lysates 


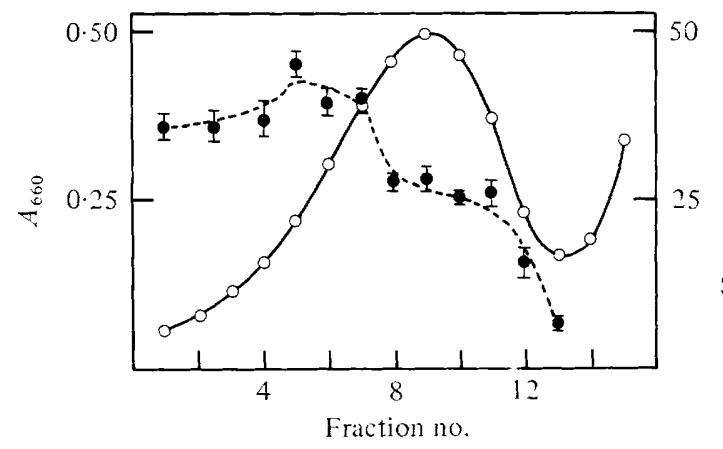

Fig. 2(a)

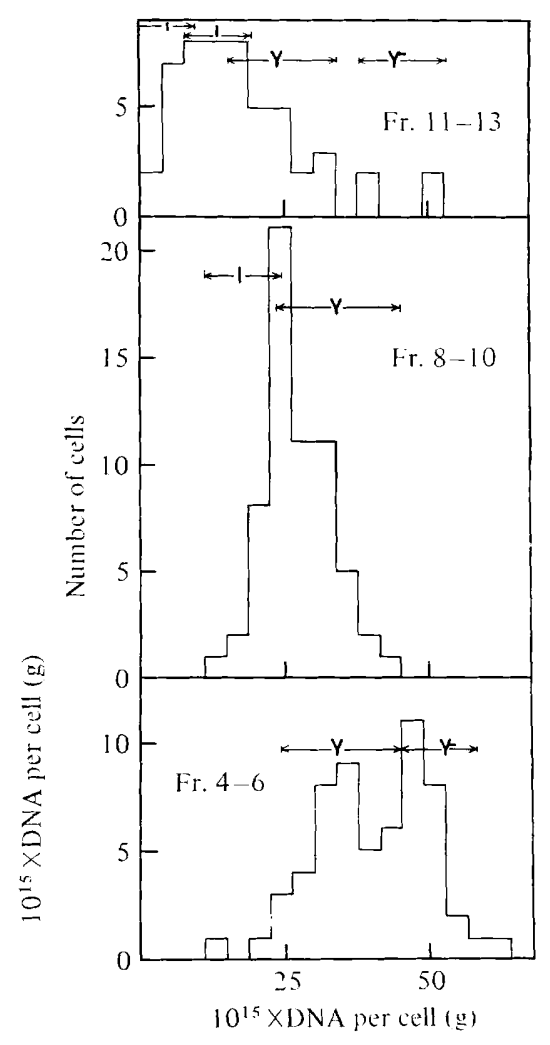

Fig. $2(b)$

Fig. 2. DNA content per cell as measured by cytofluorometry. (a) Bacteroids from 21 d-old pea nodules were separated by gradient centrifugation and $A_{660}(O)$ and DNA per cell $(\odot)$ were measured. Values of DNA per cell are given with the S.E.M. of 40 measurements. (b) Histogram of the distribution of DNA content per cell. Fractions 11 to 13,8 to 10 and 4 to 6 of the gradient shown in $(a)$ were pooled and the DNA content per cell was measured for a number of cells. The symbols I, Y and $Y$ represent rods (including bacteria), branched and extra-branched forms, respectively.

contained the maximum amount of acid-precipitable radioactivity did not coincide with the maximum in $A_{660}$ measurements (Fig. 3). The larger bacteroids had apparently incorporated less ${ }^{35} \mathrm{~S}$ into protein than had the smaller ones. By determining the protein concentration of each of the lysates and calculating the amount of acid-precipitable radioactivity per $\mu \mathrm{g}$ protein, we found that the amount of protein synthesized during the $24 \mathrm{~h}$ labelling period was greatest in the smallest bacteroids (Fig. 3).

\section{Amounts of nitrogenase components synthesized in different types of bacteroids}

To investigate which proteins are present in the different types of bacteroids and which proteins are being synthesized preferentially during the $24 \mathrm{~h}$ labelling period, bacteroid fractions from the gradient (Fig. 3) were lysed and the proteins were analysed by SDSpolyacrylamide gel electrophoresis according to Laemmli (1970). Gradient separation and lysis of the bacteroids were done under anaerobic conditions to avoid loss of nitrogenase components as an insoluble form (T. Bisseling, unpublished). Figure 4 shows typical gel patterns of the soluble proteins from a number of bacteroid fractions. Component I (MoFe protein) and component II (Fe protein) of nitrogenase were identified using purified nitrogenase components as markers (Bisseling et al., 1978). [We now routinely use Serva brand SDS which causes component I to be split into two bands (Kennedy et al., 1976).] The 


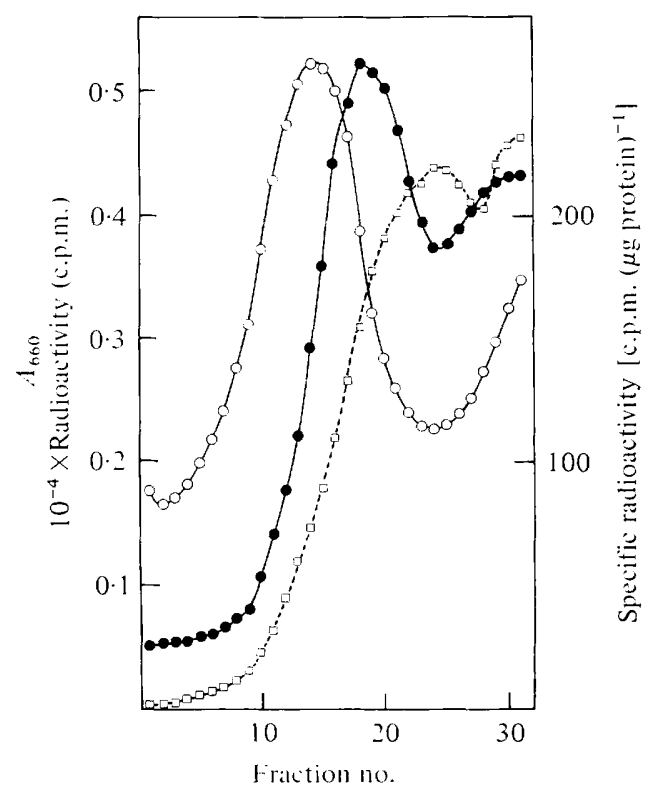

Fig. 3. Sucrose gradient sedimentation of bacteroids from $21 \mathrm{~d}$-old pea nodules after $24 \mathrm{~h}$ labelling with ${ }^{35} \mathrm{SO}_{4}{ }^{2-}$ in vivo. Conditions of growth, labelling of plants and isolation of bacteroids are described in Methods. Fractions of the gradient were monitored for $A_{660}(\bigcirc)$, acid-precipitable radioactivity was determined in $50 \mu \mathrm{l}$ bacteroid lysate (๑) and specific radioactivity [c.p.m. ( $\mu \mathrm{g}$ protein $\left.)^{-1}\right]$ was calculated for each lysate $([1)$.

resulting electrophoresis patterns (Fig. 4) show that the relative intensities of the two nitrogenase components are not constant over the different fractions. The larger bacteroids tend to contain slightly more component II relative to component I than do the smaller bacteroids.

To see if these differences were reflected in the relative amounts of the two components synthesized during a $24 \mathrm{~h}$ labelling period with ${ }^{35} \mathrm{SO}_{4}{ }^{2-}$, the bands obtained with labelled bacteroids were cut from the gel and the amount of radioactivity in each was measured (Bisseling et al., 1978). The rest of the gel was treated similarly so that the amount of ${ }^{35} \mathrm{~S}$ incorporated into the two components could be expressed as a percentage of the total ${ }^{35} \mathrm{~S}$ in proteins with molecular weights above 15000 . The results are summarized in Table 1 . The relative amount of ${ }^{35} \mathrm{~S}$ incorporated into both nitrogenase components was highest in the faster sedimenting bacteroids. Towards the meniscus of the gradient the percentage of incorporation into both components decreased, but this was more marked for component II than for component I. The relative incorporation of radioactivity into nitrogenase components paralleled the intensities of the stained bands in SDS gels (Fig. 4). Obviously nitrogenase components are not synthesized in a constant ratio in the different stages of bacteroid development.

\section{Acetylene reduction by bacteroids after gradient centrifugation}

To measure acetylene reduction by isolated rhizobium bacteroids using the method of Van Straten \& Roelofsen (1976), the cell wall is made permeable to ATP and $\mathrm{S}_{2} \mathrm{O}_{4}{ }^{2-}$ by treatment with toluene. The rate of acetylene reduction by toluene/EDTA treated cells should therefore be proportional to the amount of nitrogenase in the cell. The maximum amount of nitrogenase so measured in fractions collected anaerobically from a sucrose gradient did not coincide with the maximum $A_{660}$ value (Fig. 5), there being a slight shift towards the bottom of the gradient. A second maximum, or occasionally a shoulder, in the 


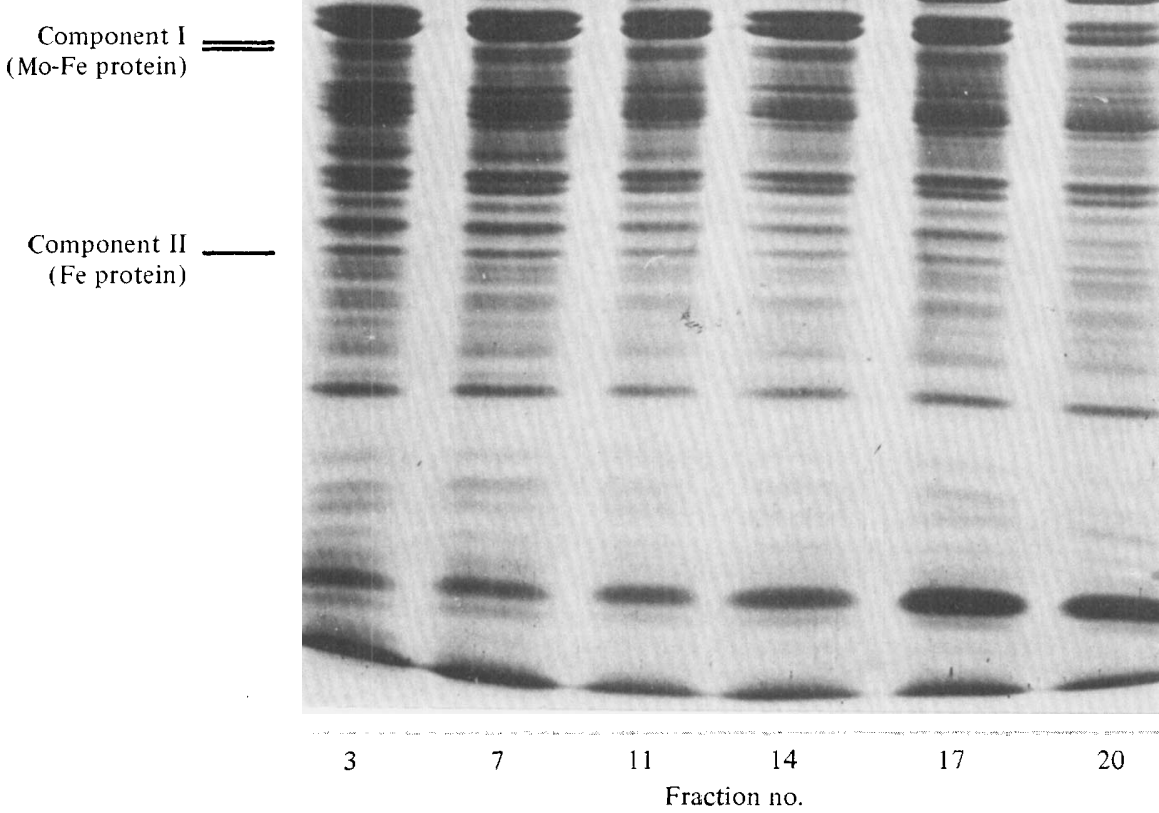

Fig. 4. SDS-polyacrylamide gel electrophoresis of lysate proteins (20 to $100 \mu 1)$ from gradient fractions of Fig. 3. The positions of components I and II of nitrogenase are indicated.

\section{Table 1. Percentage of total ${ }^{35} S$ incorporated in component I and component II of nitrogenase by bacteroids of $R$. leguminosarum of different ages}

Samples $(50 \mu \mathrm{l})$ of lysate from each fraction of a sucrose gradient similar to that shown in Fig. 3 were analysed by SDS-gel electrophoresis. After staining the gel with Coomassie Brilliant blue, the bands corresponding to components I and II of nitrogenase were cut out and the radioactivity in each was determined (Bisseling et al., 1978). The radioactivity in the rest of the gel, including proteins down to mol. wt 15000 , was determined similarly.

(a) ${ }^{35} \mathrm{~S}$ incorporation

Fraction no.

3
7
11
14
17
20
24
28
into component I $(\%)$

$11 \cdot 5$

$13 \cdot 2$

$13 \cdot 4$

$12 \cdot 4$

$10 \cdot 8$

$9 \cdot 1$

$7 \cdot 1$

$4 \cdot 1$ (b)

${ }^{35} \mathrm{~S}$ incorporation into component II

$\begin{array}{cc}(\%) & \text { Ratio }(b / a) \\ 7.0 & 0.61 \\ 8.4 & 0.64 \\ 7.9 & 0.59 \\ 7 \cdot 2 & 0.58 \\ 4.5 & 0.42 \\ 4.4 & 0.48 \\ 3.0 & 0.42 \\ 1.0 & 0.24\end{array}$




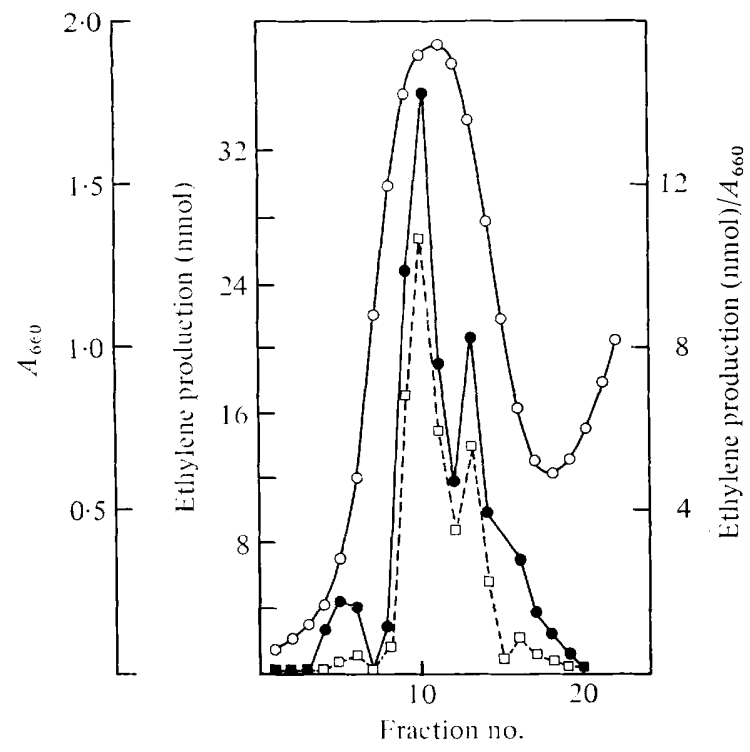

Fig. 5. Acetylene reduction of bacteroids separated on a sucrose gradient. Bacteroids from 21 d-old nodules were fractionated by centrifugation in an anaerobic sucrose gradient and acetylene reduction in $1 \mathrm{ml}$ fractions was measured as described in Methods. $A_{660}(\bigcirc)$, ethylene production ( $\square$ ) and ethylene production $/ A_{660}(\bullet)$ are shown. Ethylene production is expressed as nmol produced per $\mathrm{ml}$ fraction during $20 \mathrm{~min}$ incubation.

activity was consistently present in fraction 13 . The meniscus fractions of the gradient contained no nitrogenase activity.

\section{DISCUSSION}

Sucrose gradient centrifugation separates bacteroids from plant constituents. The bacteroids from pea root nodules are distributed over the gradient according to their stage of development. The different bacteroid forms - rods, $Y$ shapes and extra ramified forms arise after successive DNA replications together with an increase in cell size not followed by cell division (Bisseling et al., 1977).

Protein synthesis, measured as incorporation of ${ }^{35} \mathrm{SO}_{4}{ }^{2-}$ into soluble proteins, decreases rapidly with increasing bacteroid size. Sutton et al. (1977) found that the same was true for bacteroids isolated from Lupinus angustifolius. They reported that the incorporation of $\left[{ }^{14} \mathrm{C}\right]$ glycine into isolated bacteroids from nodules at different stages of development decreased with the age of the nodule. This decrease was attributed to an increased sensitivity of the older bacteroids to a lower osmolarity. Our results on the difference in protein synthesis between young and old bacteroids were obtained by measuring the protein synthesizing activity of bacteroids under symbiotic conditions. Whether the decrease in protein synthesis with development in our experiments is related to an altered sensitivity to lower osmolarity is unclear.

Surprisingly, component I and component II of nitrogenase did not occur in a constant ratio in bacteroids of different sizes. Nitrogenase components were most concentrated in those fractions which contained mostly $Y$-shaped bacteroids having a DNA content three to four times higher than that of a free-living bacterium. These fractions were also the most active in synthesizing nitrogenase components. Younger bacteroids, which sedimented a short distance into the gradient, contained a smaller amount of component II relative to component I and were less active in synthesizing component II. Older bacteroids, which sedimented furthest into the gradient and had a DNA content per cell of 5.6 times that of free-living bacteria, had a larger amount of component II relative to component I and were 
much more active in synthesizing component II. The synthesis of the nitrogenase components therefore does not appear to be closely coordinated. In Azotobacter vinelandii, synthesis of nitrogenase components appears to be coordinate (Davis et al., 1972; Shah et al., 1972), with the possible exception of mutant Uw38 (Brill, 1976). According to Nicholas \& Deering (1976), the repression of components I and II by ammonium in $A$. vinelandii is not coordinate though the remaining component II under ammonium is inactive. Our present results are probably more like those of Seto \& Mortenson (1974) with Clostridium pasteurianum where, during derepression, the Mo-Fe protein is synthesized first.

Nitrogenase activity is maximal when the two nitrogenase components reach an optimal ratio (Shah et al., 1975; Thorneley et al., 1975). We have no good explanation for the occurrence of a second maximum in the nitrogenase activity (see Fig. 5). It may be due to changes in the composition of the cell wall which does vary with the developmental stage (Van Brussel et al., 1977).

Young bacteroids, which are most active in synthesizing proteins as they develop into Y-shaped forms, have a low nitrogenase activity. On the other hand, in more developed bacteroids, which have a high nitrogenase activity, protein synthesis has decreased sharply. Presumably bacteroids during the early stages of their development obtain fixed nitrogen from the plant, but at a later stage they become capable of producing ammonia, which is excreted to be used by the plant for the synthesis of amino acids (Scott et al., 1976).

The authors thank Mr Houwers, Mr Van Geffen and Mr Van Velzen for the cultivation of pea plants, Drs Van Duijn and Van der Ploeg for their collaboration in the cytofluorometric DNA measurements, and $\mathrm{Mr}$ A. Hoogeveen for making the illustrations. Financial support from the Netherlands Foundation for Biological Research (BION) is acknowledged.

\section{REFERENCES}

Bisseling, T., Van den Bos, R. C., Van Kammen, A., Van der Ploeg, M., Van Duijn, P. \& Houwers, A. (1977). Cytofluorometrical idetermination of the DNA contents of bacteroids and corresponding broth-cultured Rhizobium bacteria. Journal of General Microbiology 101, 79-84.

Bisseling, T., Van den Bos, R. C. \& Van Kammen, A. (1978). The effect of ammonium nitrate on the synthesis of nitrogenase and the concentration of leghemoglobin in pea root nodules induced by Rhizobium leguminosarum. Biochimica et biophysica acta 539, 1-11.

BRILL, W. J. (1976). Control of nitrogenase synthesis in Azotobacter vinelandii. In Symbiotic nitrogen fixation (International Biological Programme 7), pp. 39-46. Edited by P. S. Nutman. Cambridge: Cambridge University Press.

Davis, L. C., Shah, V. K., Brill, W. J. \& OrmeJornson, W. H. (1972). Nitrogenase. II. Changes in the EPR signal of component I (iron-molybdenum protein) of Azotobacter vinelandii nitrogenase during repression and derepression. Biochimica et biophysica acta 256, 512-523.

Kennedy, C., Eady, R. R., Kondorosi, E. \& Klavans Rexosh, D. (1976). The molybdenumiron protein of Klebsiella pneumoniae nitrogenase. Evidence for non-identical subunits from peptide 'mapping'. Biochemical Journal 155, 383-389.

KIJNE, J. W. (1975). The fine structure of pea root nodules. 2. Senescence and disintegration of the bacteroid tissue of Rhizobium leguminosarum. Physiological Plant Pathology 7, 17-21.

LAEMMLI, U.K. (1970). Cleavage of structural proteins during the assembly of the head of bacteriophage T4. Nature, London 227, 680-685.

Lowry, O. H., Rosebrough, N. J., Farr, A. L. \& RANDALL, R. J. (1951). Protein measurement with the Folin phenol reagent. Journal of Biological Chemistry 193, 265-275.

Nicholas, D. J. D. \& DeERING, J. V. (1976). Repression, derepression and activation of nitrogenase in Azotobacter vinelandii. Australian Journal of Biological Sciences 29, 147-161.

Reijnders, L., Visser, L., Aalbers, A. M. J., Van Kammen, A. \& Houwers, A. (1975). A comparison of DNA from free living and endosymbiotic Rhizobium leguminosarum (strain PRE). Biochimica et biophysica acta 414, 206-216.

ScotT, D. B., FARnden, K. J. F. \& Robertson, J. G. (1976). Ammonia assimilation in lupin nodules. Nature, London 263, 703-705.

Seto, B. \& Mortenson, L. E. (1974). In vivo kinetics of nitrogenase formation in Clostridium pasteurianum. Journal of Bacteriology 120, 822830.

ShaH, V. K., Davis, L. C. \& Brill, W. J. (1972). Nitrogenase. I. Repression and derepression of the iron-molybdenum and iron proteins of nitrogenase in Azotobacter vinelandii. Biochimica et biophysica acta 256, 498-511.

Shah, V. K., Davis, L. C. \& Brill, W. J. (1975). Nitrogenase. VI. Acetylene reduction assay: dependence of nitrogen fixation estimates on component ratio and acetylene concentration. Biochimica et biophysica acta 384, 353-359.

Sutton, W. D. \& Mahoney, P. (1977). Preparation 
and fractionation of Rhizobium bacteroids by zone sedimentation through sucrose gradients. Plant Physiology, 60, 800-802.

Sutton, W. D., Jepsen, N. M. \& Shaw, B. D. (1977). Changes in the number, viability and aminoacid incorporating activity of Rhizobium bacteroids during lupin nodule development. Plant Physiology 59, 741-744.

Sutton, W. D., VAN den Bos, R. C. \& Bisseling, T. (1978). The DNA content of Rhizobium lupini bacteroids and bacteria. Plant Science Letters 12, 145-149.

Thorneley, R. N. F., EADY, R. R. \& YATES, M. G (1975). Nitrogenases of Klebsiella pneumoniae and Azotobacter chroococcum. Complex formation between the component proteins. Biochimica et biophysica acta 403, 269-284.

VAN BRUSSEL, A. A. N. (1973). The cell wall of bacteroids of Rhizobium leguminosarum Frank. Ph.D. thesis, University of Leiden, The Netherlands.

Van Brussel, A. A. N., Planqué, K. \& Quispel, A. (1977). The wall of Rhizobium leguminosarum in bacteroid and free-living forms. Journal of General Microbiology 101, 51-56.

VAN Straten, J. \& RoelofSen, W. (1976). Improved method for preparing anaerobic bacteroid suspensions of Rhizobium leguminosarum for the acetylene reduction assay. Applied and Environmental Microbiology 31, 859-863. 